\title{
An at-grade stabilization structure impact on runoff and suspended sediment
}

\author{
K.R. Minks, B. Lowery, F.W. Madison, M.D. Ruark, D. Frame, T. Stuntebeck, and M. Komiskey
}

\begin{abstract}
In recent years, agricultural runoff has received more attention as a major contributor to surface water pollution. This is especially true for the unglaciated area of Wisconsin, given this area's steep topography, which makes it highly susceptible to runoff and soil loss. We evaluated the ability of an at-grade stabilization structure (AGSS), designed as a conservation practice to reduce the amount of overland runoff and suspended sediment transported to the surface waters of an agricultural watershed. Eight years of storm and baseflow data collected by the US Geological Survey-Wisconsin Water Science Center on a farm in west central Wisconsin were analyzed for changes in precipitation, storm runoff volume, and suspended sediment concentration before and after installation of an AGSS. The agricultural research site was designed as a paired watershed study in which monitoring stations were installed on the perennial streams draining both control and treatment watersheds. Linear mixed effects model analyses were conducted to determine if any statistically significant changes occurred in the water quality parameters before and after the AGSS was installed. Results indicated no significant changes $(p=0.51)$ in average event precipitation and runoff volumes before and after installation of the AGSS in either the treatment (NW) or control (SW) watersheds. However, the AGSS did significantly reduce the average suspended sediment concentration in the event runoff water $(p=0.02)$ in the NW from 972 to $263 \mathrm{mg} \mathrm{L}^{-1}$. In addition, particle size analyses, using light diffraction techniques, were conducted on soil samples taken from within the AGSS and adjacent valley and ridge top to determine if suspended sediments were being retained within the structure. Statistical analysis revealed a significantly $(p<0.001)$ larger proportion of clay inside the AGSS (37\%) than outside (30\%). These results indicate that the AGSS was successful in reducing the amount of suspended sediment transported to nearby surface waters. The cost of an AGSS can range from US $\$ 3,500$ to US $\$ 8,000$, depending on size. Thus, these structures provide a cheap and effective means of improving water quality in highly erosive landscapes.
\end{abstract}

Key words: agricultural runoff-paired watershed—sediment transport-soil erosionunglaciated area

\begin{abstract}
Runoff and soil erosion have been a problem both agriculturally and environmentally in the unglaciated area of Illinois, lowa, Minnesota, and Wisconsin, dating as far back as the 1930s. Research conducted by Helms et al. (1996) estimated the 1930s annual erosion rate for the unglaciated area to be $33.4 \mathrm{t} \mathrm{ha}^{-1}\left(14.9 \mathrm{tn} \mathrm{ac}^{-1}\right)$. However, by 1992, this rate was reduced to $14.1 \mathrm{t} \mathrm{ha}^{-1}\left(6.3 \mathrm{tn} \mathrm{ac}^{-1}\right)$, largely as a result of changes in land use and the adoption of conservation practices. Other researchers have also attributed changes in land use and conservation throughout the unglaciated area since the 1930 s to reductions in runoff
\end{abstract}

and erosion and to increases in infiltration and baseflow (Potter 1991; Gebert and Krug 1996; Krug 1996; Juckem et al. 2008).

Erosion in the unglaciated area is dominated by storm runoff events removing soil from the landscape, transporting this soil down slope, and depositing it in nearby surface waters. This deposition has negative impacts on both surface water quality and aquatic organisms. A study of Wisconsin streams by Corsi et al. (1997) reported that 93\% to 95\% of the total annual suspended sediment loadings in the unglaciated area were the result of storm runoff events. This same report also indicated that watersheds within the unglaci- ated area had the highest total average annual suspended solids/sediment yield, at $73.2 \mathrm{t}$ $\mathrm{km}^{-2} \mathrm{y}^{-1}$ (209 tn $\left.\mathrm{mi}^{-2} \mathrm{yr}^{-1}\right)$, compared to other ecoregions of Wisconsin. Average annual sediment yields for Wisconsin's Northern Lakes and Forests and Southwestern Till Plains ecoregions were reported as $25.6 \mathrm{t} \mathrm{km}^{-2} \mathrm{y}^{-1}$ $\left(73 \mathrm{tn} \mathrm{mi}^{-2} \mathrm{yr}^{-1}\right)$ and $11.4 \mathrm{t} \mathrm{km}^{-2} \mathrm{y}^{-1}(32.4 \mathrm{tn}$ $\mathrm{mi}^{-2} \mathrm{yr}^{-1}$ ), respectively.

The use of an at-grade stabilization structure (AGSS) may potentially reduce the sediment loading to nearby surface waters. This structure consists of a large embankment that is designed to retain storm runoff long enough to allow the settling out of transported sediments. It also serves as a sink in which these sediments can be stored for a specified time period. In this fashion, it is very similar in function to sedimentation basins and detention ponds commonly used in both the mining and construction industries. However, researchers have now begun looking at the use of basins and ponds within agricultural systems as a means of controlling nonpoint pollution. The major difference between the AGSS in comparison to ponds and basins is that the AGSS allows the infiltration of retained water.

The size of each AGSS is dependent on the size of the drainage basin in which it is installed (the larger the drainage basin, the larger the AGSS). Costs associated with the installation of each structure can range from US $\$ 3,500$ to US $\$ 8,000$, depending on size and location (Tom Schultz, personal communication, November 2010). In addition, the amount of land disturbed is also minimal. Only approximately 0.81 ha $(2 \mathrm{ac})$ of the 174 ha $(430 \mathrm{ac})$ watershed was needed for the installation of the AGSS.

Sedimentation basins and detention ponds have been shown to be very effective conservation practices in trapping transported sediments. Research conducted by Edwards

Kyle R. Minks is a conservation/nutrient specialist with the Land Conservation Division, Dane County Department of Land and Water Resources, Madison, Wisconsin. Birl Lowery and Fred W. Madison are professors, and Matthew D. Ruark is an assistant professor in the Department of Soil Science, University of Wisconsin-Madison, Madison, Wisconsin. Dennis Frame is a professor at the University of Wisconsin-Extension, Pigeon Falls, Wisconsin. Todd Stuntebeck and Matt Komiskey are physical scientists at the US Geological Survey, Wisconsin Water Science Center, Madison, Wisconsin. 
et al. (1999) used simulated agricultural runoff to determine the trapping efficiency of a sedimentation basin and reported reductions of $94 \%$ in suspended sediment. Czapar et al. (2005) evaluated various conservation practices (no-tillage, contour farming, etc.) and concluded that sedimentation basins had the lowest annual soil losses at $7.3 \mathrm{~kg} \mathrm{ha}^{-1}$ $\left(0.4 \mathrm{tn} \mathrm{ac}^{-1}\right)$. Fiener et al. (2005) reported the trapping efficiencies of suspended sediments for four different detention ponds installed within agricultural watersheds to be between $54 \%$ and $85 \%$. Runoff with total suspended solid concentrations of about $200 \mathrm{mg} \mathrm{L}^{-1}$ were also reported to have decreased to levels between 5 and $20 \mathrm{mg} \mathrm{L}^{-1}$ with the installation of a sedimentation basin (Barrett 2008).

The purpose of this study was to determine if an AGSS can be used to reduce the amount of runoff and suspended sediment transported to nearby surface waters of an agricultural watershed located in the unglaciated area of western Wisconsin. To achieve this, two adjacent watersheds were evaluated for nonfrozen ground, paired storm event, precipitation $(\mathrm{mm})$, runoff $\left(\mathrm{L} \mathrm{s}^{-1}\right)$, and suspended sediment concentrations $\left(\mathrm{mg} \mathrm{L^{-1 }}\right)$ before and after the installation of the AGSS. In addition, soil samples taken from within the AGSS and adjacent valley and ridge top were also evaluated to determine whether or not sedimentation was occurring. It was predicted that the installation of the AGSS would reduce the amount of storm runoff and concentrations of suspended sediments within the surface waters of the treatment watershed as well as increase the amount of clay-sized material within soil samples taken within the AGSS.

\section{Materials and Methods}

Site Description. This study was conducted on both the north (NW) and south (SW) tributary watersheds of Traverse Valley Creek, which are located in the headwaters of the Middle Trempealeau RiverWatershed, Buffalo County, Wisconsin, in the unglaciated portion of the state (figure 1). Landscapes in this area are controlled by the underlying dolostone and are characterized as having flat top ridges, steep side slopes, and narrow valleys. The ridges and valleys of this region also tend to be very productive because of windblown loess deposits overlying Ordovician-age rocks. Soils in both watersheds consist of Dubuque silt loams (fine-silty, mixed, superactive, mesic Typic Hapludalfs) dominating the ridge tops,

\section{Figure 1}

Location of north and south Traverse Valley Creek Watersheds as well as stream and rain gages.

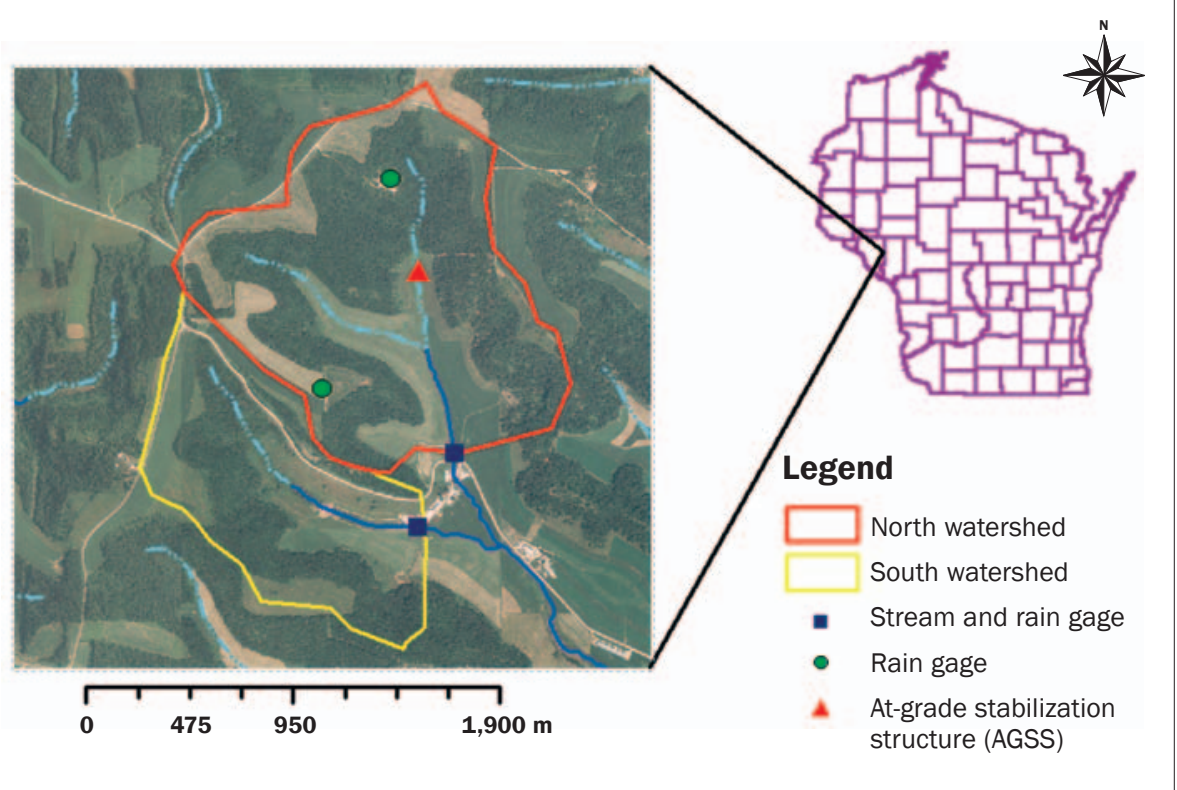

\section{Figure 2}

Cross-sectional view of the at-grade stabilization structure embankment that was installed in the north watershed (USDA NRCS 2005).

Profile along centerline of principle spillway
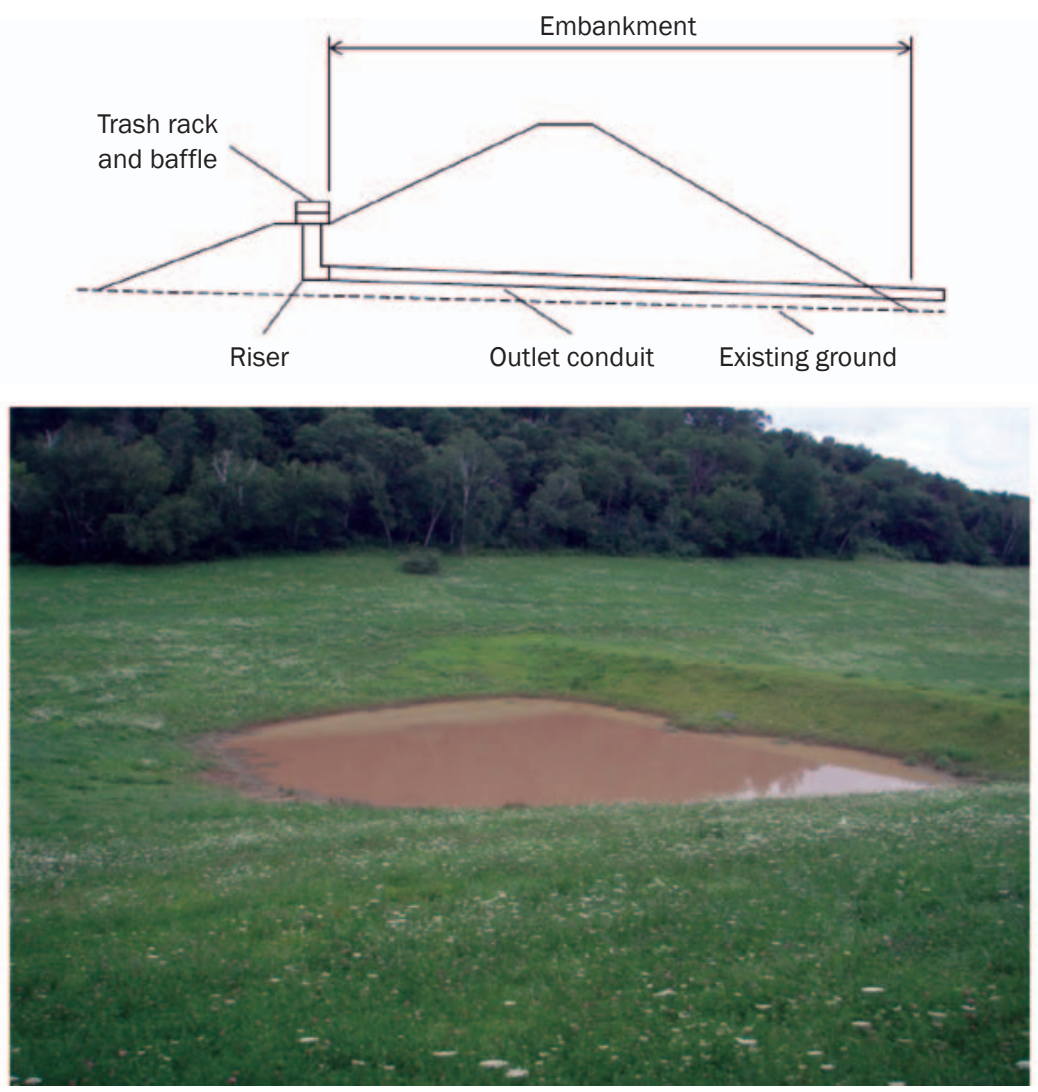
Dorerton very stony (loamy-skeletal, mixed, active, mesic Typic Hapludalfs) and Elbaville complex (fine-loamy, mixed, superactive, mesic Glossic Hapludalfs) occupying much of the steep side slopes, and Fayette silt loam (fine-silty, mixed, superactive, mesic Typic Hapludalfs) and Norden silt loam (fine-silty, mixed, superactive, mesic Typic Hapludalfs) comprising the majority of soils in the valleys (USDA NRCS 2009a, 2009b). The average annual temperature is $-8.4^{\circ} \mathrm{C}\left(16.8^{\circ} \mathrm{F}\right)$ in winter and $20.3^{\circ} \mathrm{C}\left(68.5^{\circ} \mathrm{F}\right)$ in summer. Average annual precipitation and snowfall for the unglaciated area of Wisconsin are 846.8 $\mathrm{mm}$ (33.34 in) and 1,150.6 $\mathrm{mm}$ (45.30 in), respectively (Wisconsin State Climatology Office 2007).

The two watersheds are part of a private farm participating in the University of Wisconsin-Discovery Farms Program. The treatment watershed (NW) was located on the north tributary of Traverse Valley Creek and was 174 ha $(430 \mathrm{ac})$ in size (figure 1). Most of the landscape was forested, 102 ha (253 ac), with approximately 60.7 ha (150 ac) being used for agricultural crop production. The control watershed (SW) was located on the south tributary of Traverse Valley Creek and was 87 ha $(215 \mathrm{ac})$ in size (figure 1). The dominant land cover was forest, 41 ha (101 $\mathrm{ac})$, and 30 ha $(73 \mathrm{ac})$ of the land was being used for hay, pasture, or was enrolled in the Natural Resources Conservation ServiceConservation Reserve Program.

At-Grade Stabilization Structure. One AGSS was installed in the NW (treatment watershed) in June 2005. The structure has a life expectancy of 15 years, but it must be cleaned every 5 to 10 years (Patrick Murphy, personal communication, June 2011). Storm event stream flow and water quality data were collected in both the NW and SW before installation of the AGSS (October $1,2001$, to June 11,2005$)$ as well as after installation (July 25, 2005, to September 30, 2008). The AGSS was located in the north central portion of the NW and was designed and installed according Natural Resources Conservation Service specifications (USDA NRCS 2005). The embankment (figure 2)

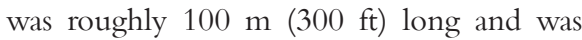
constructed at the base of the forested hillside, bisecting the drainage flow path of the valley. The AGSS was installed at this location as a result of observations by the landowner indicating that a substantial amount of soil was being eroded from the ridge top fields and forested hill slope. Installing the structure at this location ensured the greatest possibility in trapping runoff transported sediments. The AGSS was equipped with a $76.2 \mathrm{~cm}(30$ in) diameter, $0.16 \mathrm{~cm}$ (0.064 in) thick metal stand pipe and animal guard placed approximately $3 \mathrm{~m}(10 \mathrm{ft})$ below the embankment to prevent overtopping. The stand pipe was then connected to a $30 \mathrm{~m}$ (100 ft) long, 0.16 $\mathrm{cm}(0.064$ in) thick metal flow pipe positioned at a $4.8 \%$ grade running underneath the embankment (figure 2).

Runoff and Suspended Sediment. Stream gaging stations as well as rain gages were installed by the US Geological Survey-Wisconsin Water Science Center (USGS-WWSC) at the outlet of each watershed (figure 1). All sampling methods were conducted in accordance with USGS methods (Stuntebeck et al. 2008). Streamflow was estimated using a standard stage (water level)/discharge relation for a $1.37 \mathrm{~m}(4.5 \mathrm{ft})$ $\mathrm{H}$-flume at the NW gage and a $1 \mathrm{~m}(3 \mathrm{ft})$ $\mathrm{H}$-flume at the SW gage. Water levels were determined by use of Sutron Corporation (Sterling, Virginia) Accubar nonsubmersible pressure transducers coupled with nitrogen bubbler systems. Water levels were recorded every 15 or 60 minutes during nonrunoff events and every 1 to 5 minutes during events using Campbell Scientific Inc. (Logan, Utah) CR10 or CR10X dataloggers and H-flumes coupled with nonsubmersible pressure transducers and nitrogen bubbler systems. Runoff events were determined to be occurring when a threshold level of 30 to $60 \mathrm{~mm}(0.1$ to $0.2 \mathrm{ft}$ ) above the preevent baseflow water level was exceeded in the H-flume.

Each station was also equipped with a Campbell Scientific, Inc. (Logan, Utah) COM 210 telephone modem, a Campbell Scientific, Inc. RF400 spread-spectrum radio/ modem, and an omnidirectional antenna allowing for two-way, real-time communication. This allowed USGS-WWSC personnel to adjust sampling frequencies during a runoff event, ensuring sufficient sampling over a range of runoff volumes and durations. This also ensured that equipment was functioning properly during events.

Surface water runoff samples were collected using volume-paced sampling and automated, refrigerated, 24-bottle ISCO 3700R samplers (Teledyne ISCO, Lincoln, Nebraska). Samples were pumped from an intake hose located near the center of each H-flume, approximately $5 \mathrm{~cm}$ (2 in) above the flume floor. Total storm runoff volumes, peak discharges, and sample threshold values needed to first be estimated in order to determine the volume of runoff that would need to pass through the $\mathrm{H}$-flume between samples. Runoff volumes and threshold values were based on anticipated precipitation amounts and intensities, antecedent moisture conditions, and time of the year using online weather stations and Doppler radar. The sampling threshold was set equal to or slightly greater than the runoff threshold of 30 to 60 $\mathrm{mm}(0.1$ to $0.2 \mathrm{ft})$ above the preevent baseflow water level. Before and after each sample was taken, the sample-intake line was purged to ensure no cross contamination between events. The ISCO sampler was calibrated to deliver two discrete volume-paced samples per sampling bottle. Sample bottles were refrigerated until sample pickup (within 24 hours), upon which they were labeled and transported under ice to the USGS-WWSC to be split. After splitting, the samples were sent to Wisconsin State Laboratory of Hygiene (WSLH) in Madison, Wisconsin, for analysis. Quality assurance and quality control were conducted once a year. Field blanks consisting of deionized water were used to determine if there was any contamination introduced from the entire sampling process. Concurrent-replicate samples were also taken from the outlet of the $\mathrm{H}$-flume and the automatic sampler to determine whether samples taken at the tip of the sample-intake line were representative of the concentrations within the water column. In addition, monthly grab samples for baseflow were taken during times when no overland flow was contributing to streamflow.

Storm event start times were determined when the stage or discharge hydrograph rose 30 to $60 \mathrm{~mm}(0.1$ to $0.2 \mathrm{ft})$ above the preevent baseflow water levels. The event end time was determined by plotting the hydrograph and placing a line, by hand, along the slope of the recession line 6 hours after the event was assumed to have stopped (line 1) (figure 3 ). The slope of line 1 is in essence 0 since it represents steady state baseflow conditions. Starting at the inflection point where line 1 diverges from the recession limb of the hydrograph, a second line (line 2) was drawn based on the slope of the recession limb. The end time was then determined to be at the point where the recession limb began to diverge from line 2 . 
Figure 3

A runoff hydrograph showing US Geological Survey methods for determining start and end times of runoff events (Stuntebeck et al. 2008).

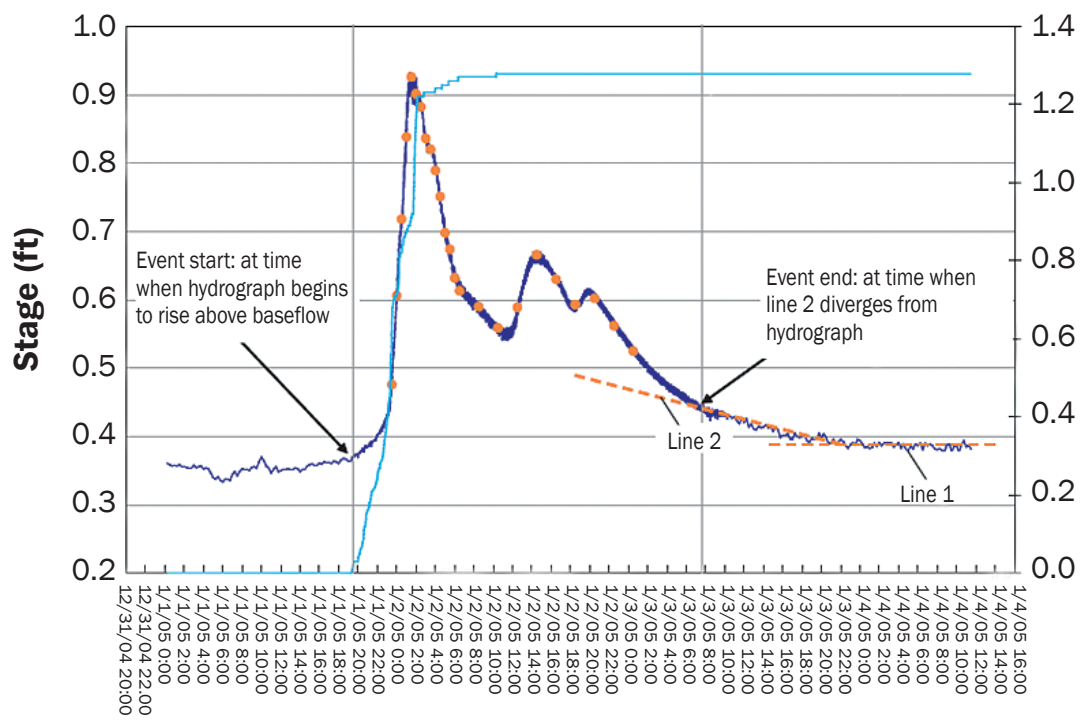

Legend

_ Original CR10 stage

- Sample time

— Rainfal

All of the discrete volume-paced samples that fell within the start and end time of the event were used to form a composite sample for constituent analysis. If the end time occurred between the first and second discrete collection, then one-half of that bottle was used in the composite sample. All of the discrete samples within an event were combined into either an 8 or $14 \mathrm{~L}$ (2.1 or 3.7 gal) polyethylene churn splitter (depending on the number of samples) and agitated with a churn paddle at a rate greater than $22.9 \mathrm{~cm}$ $\mathrm{s}^{-1}\left(9\right.$ in $\left.\mathrm{sec}^{-1}\right)$. Water samples were then dispensed from the churn splitter into WSLH bottles. The volume between samples was sometimes changed during events to ensure complete sampling of the event. In these cases, discrete samples were added to the polyethylene churn splitter based on a weighted volume of the event, and an average event mean concentration was recorded. Events that were not sampled completely or experienced sampling malfunction were not analyzed. Concentrations of suspended sediment were analyzed using WSLH ESS INO METHOD 340.1 protocol. This protocol is based on standard methods developed by the American Public Health Association, American Water Works Association, Water Environment Federation (1998) and the US Environmental Protection Agency (1983). The WSLH is also certified by the State of Wisconsin for analyzing water quality samples.

Four rain gages were placed within the watersheds. One rain gage was placed at each stream gaging station as well as two others on the ridge tops (figure 1). Campbell Scientific Inc. (Logan, Utah) 107 soil temperature probes were inserted into the soil at a depth of $15 \mathrm{~cm}$ (5.91 in), and maximum, minimum, and mean daily temperatures were recorded. Precipitation data were collected using RainWise Inc. (Bar Harbor, Maine) tipping-bucket rain gages installed on either wooden or galvanized pipes approximately $2.13 \mathrm{~m}(7 \mathrm{ft})$ off the ground and away from any overhead obstructions. All of the data were recorded using Campbell Scientific, Inc. CR10 dataloggers. Each rain gage was calibrated at least once annually.

Monthly baseflow volumes were recorded at both NW and SW sites. Water samples were also collected during monthly baseflow recordings and were sent to the WSLH to determine suspended sediment concentrations. Data collected during storm runoff events contained both baseflow volumes and corresponding baseflow suspended sediment concentrations. Thus, monthly baseflow volumes and baseflow suspended sediment concentrations were removed from runoff event volumes and concentrations that occurred within the same month. This allowed for the comparison, between the two basins, of only surface-generated runoff and subsequent suspended sediment concentrations.

Only paired storm events that occurred on nonfrozen ground were used in this study. Paired events were those that occurred during the same time in both the NW and SW. Nonfrozen ground, for the purpose of this study, was defined as the time during which all soil temperature probes, in both watersheds, had average daily temperature readings above $0^{\circ} \mathrm{C}\left(32^{\circ} \mathrm{F}\right)$. Total storm runoff volumes (SRV) for each event were calculated by subtracting the storm flow volume (SFV) from the monthly instantaneous baseflow $(M B F)$ multiplied by the event duration $(E D)$ :

$S R V=S F V-(M B F \times E D)$.

This method caused some abnormalities among storm runoff volumes. Storms that occurred on November 18, 2001, and April 27, 2002, had negative runoff values as a result of the calculated baseflow value being greater than the storm flow volume. Thus, these two events were removed from the statistical analysis. In addition, events that were not sampled for the entire duration of the storm event or did not have at least 120 min between rain events were removed from the analysis.

Storm event precipitation runoff volumes and suspended sediment concentrations were evaluated using SAS 9.2 (SAS Institute, Cary, North Carolina), Windows-based software and a linear mixed effects (LME) model to determine significant changes within mean variable values before and after installation of the AGSS. Values for both storm runoff concentrations and suspended sediment concentrations were natural $\log (\mathrm{Ln})$ transformed in order to hold normality assumptions within statistical modeling. The model can be rewritten as:

$Y=\left(n s_{i}\right) b a_{j}+e v_{k}+e_{i j k}$,

where $Y$ is the variable of interest (precipitation, Ln runoff, or Ln suspended sediment); $n s$, is the location of the measurement in either the north (n) or south (s) watershed; $b a$. denotes whether the measurement was taken before (b) or after (a) installation of the AGSS; $e v_{k}$ is the random event and defines the storm event which has taken place in both watersheds; and $e_{i j k}$ is the error associated with the above three parameters. Storm 
event was characterized as a random variable because of the inability to control storm intensity or duration; storm event is a random sample of the much larger population of storm types.

A nested design was also implemented within the study. Measurements in both the NW and SW were taken in the same location both before and after installation of the AGSS. This allowed for the $b a_{j}$ factor to be nested within the nsi factor.

Basin Pairing. Preliminary analysis was conducted by the USGS-WWSC to determine if the hydrological processes in each basin were similar. Twelve storm events that occurred from October 1, 2001, to October 4, 2002 , were used in the analysis. Linear regressions were plotted for runoff volumes as well as suspended solids, total Kjeldahl $\mathrm{N}$, total phosphorus, and total dissolved phosphorus loadings, using SW as the dependent variable and NW as the independent variable. The $r^{2}$ values ranged from 0.64 to 0.96 , with statistically significant intercepts and slopes $(p<0.05)$ for all five constituents (Todd Stuntebeck, personal communication, February 2010). This indicated that the two basins were behaving similarly in regards to runoff and the transport of both nutrients and sediments.

Soil Cores and Particle Size Analysis. Eight soil cores were taken uphill of the AGSS embankment located in the north watershed (NW). Samples were taken in a "T" pattern, approximately 10 to $20 \mathrm{~m}$ (30 to $60 \mathrm{ft}$ ) apart (figure 4). This sampling pattern ensured that the soil cores contained some sediment-laden material regardless of the amount of water retained by the embankment. This sampling process was necessary because the amount of runoff retained by the AGSS is highly variable and influenced by a number of different factors, including precipitation, infiltration, and plant interception.

Soil cores were extracted by inserting

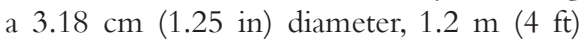
long plastic tube, housed within a steel

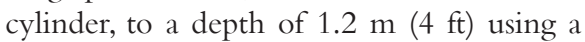
540B Geoprobe (Geoprobe Systems, Salina, Kansas) mounted on a Case 420 (Case Construction Equipment Inc., Racine, Wisconsin) skid steer. Soil core samples were then sealed shut using plastic cellophane and tape and placed into a large, sealed plastic bag for transport. Soil core tubes were cut along both sides, and soil samples sliced down the center, along the vertical, in order to view the soil profile. Two or three samples were

\section{Figure 4}

Soil core sample locations within the at-grade stabilization structure located in the north watershed of the study site. Not drawn to scale.

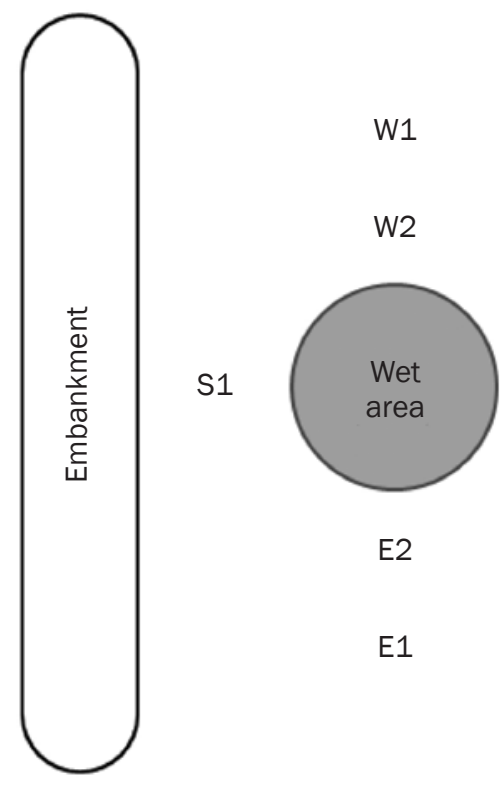

then removed from each soil core for Particle Size Analysis (PSA). Samples were taken based on pedological determinations of sediment deposition (Fred Madison, personal communication, April 2010). A complete list of the 23 PSA samples taken from the eight soil cores and corresponding depths are presented in table 1.

In addition, nine soil cores were taken outside of the AGSS, using a $3.18 \mathrm{~cm}(1.25$ in) soil hand probe (Oakfield Apparatus Company, Oakfield, Wisconsin) inserted to a depth of about $0.5 \mathrm{~m}$ (1.5 ft). Three were taken on the ridge top and six in the valley located adjacent to the AGSS (table 1). One surface sample (0 to $6 \mathrm{~cm}$ [0 to 2.36 in]) was then removed from each soil core and placed into a plastic bag to be transported to the University of Wisconsin-Madison, Department of Soil Science for PSA.

Subsamples of the 23 samples from the AGSS, along with the nine samples from the ridge and valley, were individually placed into a $400 \mathrm{~mL}$ glass beaker and stripped of organic matter using hydrogen peroxide $\left(\mathrm{H}_{2} \mathrm{O}_{2}\right)$. However, given the elevated organic matter and clay complex content of the sampled soils as a result of excessive erosion and tillage, obtaining a no-reaction state with the addition of $\mathrm{H}_{2} \mathrm{O}_{2}$ was not always possible. In these circumstances, organic matter was assumed to be removed when a consistent reaction was observed with the addition of
$\mathrm{H}_{2} \mathrm{O}_{2}$. Previous research has concluded that increased erosion and tillage result in an increase in the clay content of surface soils (Lowery et al. 1995). This study site has been highly eroded and tilled extensively, resulting in increased organic matter/clay complex in runoff sediment.

Following $\mathrm{H}_{2} \mathrm{O}_{2}$ treatment, each sample was allowed to air dry before being removed from the beaker and placed into a mortar. Sample aggregates were then broken down using a mortar and pestle until soil material passed through a $2 \mathrm{~mm}$ (0.08 in) sieve. The samples were stored in Whirl-Pak (Nasco, Fort Atkinson, Wisconsin) plastic bags for PSA.

The PSA was done using a Coulter LS230 (Beckman-Coulter Inc., Miami, Florida) laser coupled with a fluid sampler module and Windows-based computer system. Samples were processed according to methods developed by Arriaga et al. (2006). Prior to sample analysis, a $10 \mathrm{~min}$ rinse cycle was conducted to ensure that no previous residues were left in the LS230. Background measurements were then taken on the softened water containing $100 \mathrm{~mL}$ of sodium hexametaphosphate (Na-hex). This solution was created by mixing $50 \mathrm{~g}$ of $\mathrm{Na}$-hex with $1 \mathrm{~L}$ of distilled water. The addition of Na-hex helped in the dispersion of the soil particles during sonication. Upon completion of the background measurements, soil was added to the fluid module until the sen- 


\section{Table 1}

Soil core sample identification numbers taken from within the at-grade stabilization structure (AGSS), ridge, and valley with corresponding subsample depths and percentages* of sand, silt, and clay content using particle size analysis techniques.

\begin{tabular}{|c|c|c|c|c|c|c|}
\hline & $\begin{array}{l}\text { Core } \\
\text { ID † }\end{array}$ & $\begin{array}{l}\text { Core } \\
\text { sample } \\
\text { ID‡ }\end{array}$ & $\begin{array}{l}\text { Sample } \\
\text { depth } \\
\text { (cm) }\end{array}$ & $\begin{array}{l}\text { Sand } \\
(\%)^{*}\end{array}$ & $\begin{array}{l}\text { Silt } \\
\text { (\%)* }\end{array}$ & $\begin{array}{l}\text { Clay } \\
(\%)^{*}\end{array}$ \\
\hline \multirow[t]{23}{*}{ AGSS } & \multirow[t]{3}{*}{ N1 } & 1 & 0 to 2.5 & 15 & 51 & 33 \\
\hline & & 2 & 2.5 to 5 & 31 & 40 & 29 \\
\hline & & 3 & 25 to 27.5 & 49 & 32 & 19 \\
\hline & \multirow[t]{3}{*}{ N2 } & 1 & 0 to 9 & 12 & 49 & 38 \\
\hline & & 2 & 14 to 18 & 50 & 30 & 20 \\
\hline & & 3 & 34 to 38 & 26 & 46 & 28 \\
\hline & \multirow[t]{3}{*}{ N3 } & 1 & 0 to 8 & 10 & 51 & 38 \\
\hline & & 2 & 10 to 13 & 44 & 39 & 17 \\
\hline & & 3 & 15 to 19 & 58 & 25 & 17 \\
\hline & \multirow[t]{3}{*}{ W1 } & 1 & 0 to 3.5 & 11 & 50 & 38 \\
\hline & & 2 & 6.5 to 10 & 30 & 44 & 26 \\
\hline & & 3 & 19 to 23 & 10 & 53 & 36 \\
\hline & \multirow[t]{3}{*}{ W2 } & 1 & 0 to 7.5 & 7 & 52 & 41 \\
\hline & & 2 & 10 to 15 & 41 & 36 & 23 \\
\hline & & 3 & 30 to 35 & 23 & 46 & 31 \\
\hline & \multirow[t]{3}{*}{ E1 } & 1 & 0 to 5.5 & 11 & 51 & 38 \\
\hline & & 2 & 10 to 14 & 35 & 41 & 24 \\
\hline & & 3 & 43 to 47 & 20 & 51 & 29 \\
\hline & \multirow[t]{3}{*}{ E2 } & 1 & 0 to 8 & 11 & 56 & 33 \\
\hline & & 2 & 10 to 14 & 23 & 62 & 15 \\
\hline & & 3 & 36 to 40 & 12 & 62 & 26 \\
\hline & \multirow[t]{2}{*}{ S1 } & 1 & 0 to 7 & 14 & 48 & 38 \\
\hline & & 2 & 12 to 16 & 52 & 28 & 20 \\
\hline \multirow[t]{6}{*}{ Valley } & & A1 & 0 to 5 & 22 & 46 & 32 \\
\hline & & B1 & 0 to 6 & 15 & 55 & 30 \\
\hline & & $\mathrm{C} 1$ & 0 to 3.5 & 28 & 46 & 27 \\
\hline & & D1 & 0 to 4 & 31 & 42 & 27 \\
\hline & & E1 & 0 to 6 & 18 & 51 & 30 \\
\hline & & $\mathrm{F} 1$ & 0 to 5 & 32 & 41 & 27 \\
\hline \multirow[t]{3}{*}{ Ridge } & & G1 & 0 to 3 & 6 & 64 & 31 \\
\hline & & $\mathrm{H} 1$ & 0 to 4.5 & 5 & 61 & 34 \\
\hline & & 11 & 0 to 4 & 5 & 63 & 33 \\
\hline
\end{tabular}

* \% is percentage by volume of sample.

† See figure 4 for locations of N1, N2, N3, W1, W2, E1, E2, and S1 sample sites.

$\ddagger 1,2$, and 3 = samples taken from the same soil core. $A 1$ = sample taken at the top of the valley north of the AGSS, B1 = sample taken at the middle of the valley north of the AGSS, C1 = sample taken at the bottom of the valley north of the AGS, D1 = sample taken at the top of the valley south of the AGSS, E1 = sample taken at the middle of the valley south of the AGSS, F1 = sample taken at the bottom of the valley south of the AGSS, G1 = sample taken at the bottom of the ridge above the AGSS, $\mathrm{H} 1$ = sample taken at the middle of the ridge above the AGSS, and I1 = sample taken at the top of the ridge above the AGSS.

sors indicated a sufficient amount was added, obscuration and polarization intensity differential scattering readings of around $5 \%$ and $43 \%$, respectively (usually about $0.2 \mathrm{~g}$ ). The sample was then sonicated for 480 seconds to ensure soil particles were dispersed. Sensor readings were then recorded for 90 seconds upon which an optical model was applied to
The Wilcox-test was used to determine if there were any significant differences in the average soil texture between samples taken in the AGSS and those taken from the ridge and valley (Wilcoxon 1945; Mann and Whitney 1947). This type of a nonparametric statistical analysis was conducted because of the lack in normality within the data. All PSA statistical analyses were performed using $\mathrm{R}$ statistical software (R Foundation for Statistical Computing, Vienna, Austria). Significant differences in the proportion of sand, silt, and clay were determined at $p<0.05$.

\section{Results and Discussion}

Precipitation. The amount of precipitation received by the NW and SW varied for each of the 68 storm events. Differences between the two basins can be seen in figure 5 , with values $>0$ indicating more precipitation in the NW than the SW and the reverse for values $<0$. The LME analysis resulted in mean precipitation values of $31.8 \mathrm{~mm}$ (1.25 in) in the NW and $31.8 \mathrm{~mm}$ (1.25 in) in the SW before installation of the AGSS. After installation, the mean precipitation values increased slightly to $34.9 \mathrm{~mm}$ (1.37 in) in the NW and $36.3 \mathrm{~mm}$ (1.43 in) in the SW (table 2). However, evaluation for significant differences in the amount of precipitation received by each basin before and after installation of the AGSS indicated no significant change, with $p$-values $=0.50$ for the NW and 0.34 for the SW.

Evaluation for differences in the amount of precipitation between basins (NW - SW) before and after installation yielded no significant change, with $p$-values of 0.94 before and 0.13 after (table 2). Further investigation into the relatively low $p$-value between the NW and SW after installation of the AGSS revealed only a $1.5 \mathrm{~mm}$ (0.06 in) mean difference in event precipitation. This slightly higher mean event precipitation within the SW would have minimal, if any, impact on runoff processes within the basin, especially since this basin is dominated by forest and nonagricultural land uses.

Given that there is no significant change in precipitation within the NW or SW before and after installation of the AGSS, it can be concluded that the average amount of precipitation per event received by each basin did not change over the course of this study. In addition, there is no significant change between the NW and SW (NW SW) before or after installation, supporting 


\section{Figure 5}

Precipitation (mm) for each of the 68 sampled runoff events from 2001 to 2008 at both the north watershed (NW) and south watershed (SW). Differences in runoff (north - south) is also presented in the bottom plot.

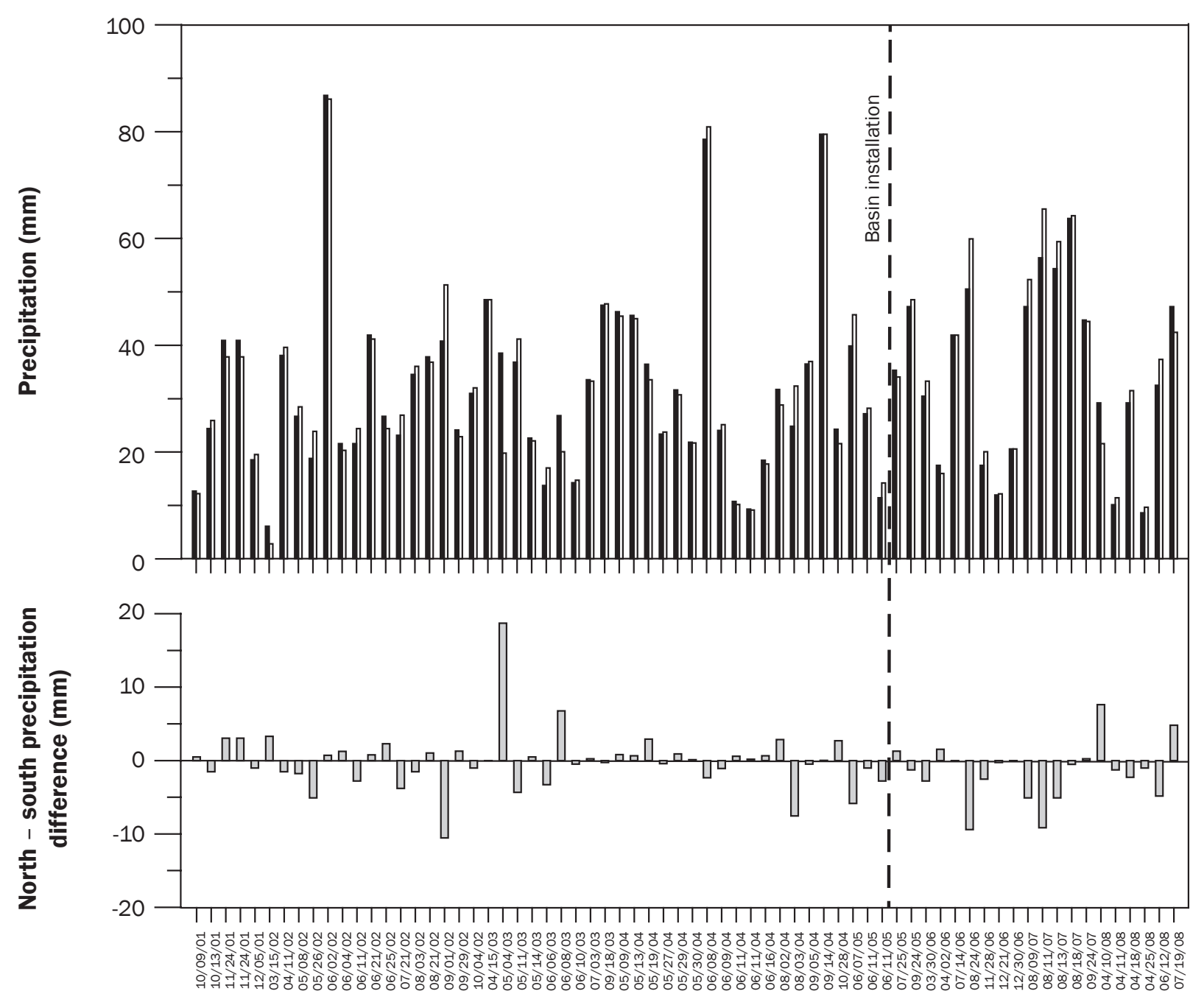

Event date

Legend

North (NW)

South (SW)

the claim that the amount of precipitation received by each basin is the same.

Runoff and Suspended Sediment. Disregarding the two large runoff events that occurred before installation of the AGSS, little change was observed in the amount of runoff occurring in both basins pre and postinstallation (figure 6). The LME model analysis of the 68 events indicated that average runoff volumes before and after installation of the AGSS in the NW were 5,448 and 5,143 L $\mathrm{ha}^{-1}$, respectively (table 2 ). Runoff event mean volumes in the SW were 2,306 $\mathrm{L} \mathrm{ha}^{-1}$ before installation of the AGSS and 1,734 L $\mathrm{ha}^{-1}$ after. Evaluation for differences in the SW before and after the treatment indicates no significant change in mean runoff volumes $(p=0.69)$ (table 2). The before and after analysis of the difference in mean runoff values in the NW resulted in a p-value of 0.15 (table 2).Variability within the amount of runoff generated during storm events before and after installation of the AGSS can explain the lack of significant difference in the NW and SW using the LME model. Even though there was no significant difference in the amount of event precipitation received by each watershed before and after installation of the AGSS, the intensities of the storms appeared to be much different. Storms that occurred before installation of the AGSS tended to be greater in intensity because of shorter durations than storms that occurred after the installation. Greater intensity storms have been linked to larger amounts of runoff as well as increased soil detachment and loss (Pruski and Nearing 2002).

Runoff variability can also be attributed to the complexity of the groundwater flow regime. Clayton and Attig (1990) reported that there are three main aquifers that dominate the unglaciated area:Jordan, Tunnel City, 


\section{Table 2}

Total precipitation, runoff minus baseflow, and runoff suspended sediment minus baseflow suspended sediment statistics using the linear mixed effects (LME) model for nonfrozen ground paired storm events within the north (NW) and south (SW) watersheds. Mean estimates are present for nonnatural log transformed data. The $p$-values are based on natural log transformed data.

\begin{tabular}{|c|c|c|c|c|}
\hline $\begin{array}{l}\text { Basin } \\
\text { before/after }\end{array}$ & $\begin{array}{l}\text { Basin } \\
\text { before/after }\end{array}$ & Precipitation & Runoff & $\begin{array}{l}\text { Suspended } \\
\text { sediment }\end{array}$ \\
\hline \multicolumn{5}{|c|}{ Event nonnatural log transformed least squares means } \\
\hline NW & Before & $31.8 \mathrm{~mm}$ & $5,448 \mathrm{~L} \mathrm{ha}^{-1}$ & $971.61 \mathrm{mg} \mathrm{L}^{-1}$ \\
\hline NW & After & $34.9 \mathrm{~mm}$ & $5,143 \mathrm{~L} \mathrm{ha}^{-1}$ & $262.86 \mathrm{mg} \mathrm{L}^{-1}$ \\
\hline SW & Before & $31.8 \mathrm{~mm}$ & $2,306 \mathrm{~L} \mathrm{ha}^{-1}$ & $310.57 \mathrm{mg} \mathrm{L}^{-1}$ \\
\hline SW & After & $36.3 \mathrm{~mm}$ & $1,734 \mathrm{~L} \mathrm{ha}^{-1}$ & $360.44 \mathrm{mg} \mathrm{L}^{-1}$ \\
\hline Number of samples & & 68 & 68 & 44 \\
\hline \multicolumn{5}{|c|}{$P$-values for event In transformed least squares means } \\
\hline NW after & SW after & 0.126 & $<0.001 *$ & 0.731 \\
\hline NW after & NW before & 0.505 & 0.155 & $0.023 *$ \\
\hline NW after & SW before & 0.510 & $<0.001 *$ & 0.583 \\
\hline SW after & NW before & 0.333 & $0.007 *$ & $0.013 *$ \\
\hline SW after & SW before & 0.337 & 0.688 & 0.430 \\
\hline NW before & SW before & 0.943 & $<0.001^{*}$ & $0.002 *$ \\
\hline
\end{tabular}

Notes: NW = north watershed (treatment). SW = south watershed (control). Before $=$ the time period before installation of the at-grade stabilization structure, August of 2001 to June of 2005. After $=$ the time period after installation of the at-grade stabilization structure, July of 2005 to August of 2008.

* Significant difference at $p<0.05$.

and Wonewoc aquifers. The USGS-WWSC groundwater seepage and recharge analysis reported that only $50 \%$ of the expected baseflow was discharged at the NW gaging site, and less than $25 \%$ at the SW site (Todd Stuntebeck, personal communication, February 2010). This is based on a 20.32 $\mathrm{cm}$ (8 in) average annual baseflow recharge for watersheds located in Buffalo County, Wisconsin (Gebert et al. 2007). Seepage runs conducted downstream of the gaging stations resulted in baseflow recharge depths closer to $20.32 \mathrm{~cm}$ (8 in). This indicates that groundwater is likely bypassing the gaging stations in both basins and reentering as surface water downstream. Since the baseflow volume component was removed from all storm runoff event volumes, inconsistencies in the data may exist. The complexity of the groundwater flow regime, coupled with the change in storm intensities and durations before and after installation of the AGSS, explains the lack of significant reduction in event runoff volumes.

The LME model showed significant differences $(p<0.05)$ in runoff between the NW and SW sites both before and after installation of the AGSS (table 2). The larger amount of runoff occurring in the NW can be attributed to the tiered farming of the dolostone con- trolled landscapes in unglaciated areas. These farming systems use both the flat top ridges and lower lying valleys for crop production while leaving the steep side slopes forested. The Rountree soil formation, which is clayrich residuum deposits from the weathering of dolomite bedrock, often underlie these ridge top settings (Frolking et al. 1983). This highly impermeable soil layer is associated with decreased infiltration rates and increased runoff. A study conducted by Juckem et al. (2008) in dolostone controlled landscapes concluded that the infiltration rates on similar ridge tops in the unglaciated area $(\sim 2.5 \mathrm{~cm}$ $\mathrm{h}^{-1}\left[0.98\right.$ in $\left.\left.\mathrm{hr}^{-1}\right]\right)$ were much less than those

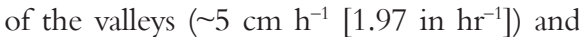
side slopes $\left(\sim 24 \mathrm{~cm} \mathrm{~h}^{-1}\left[9.45 \mathrm{in} \mathrm{hr}^{-1}\right]\right)$. The combination of a greater amount of ridge top land area in the NW, with low infiltration rates and increased soil disturbances due to agricultural practices, supports the findings of greater ruoff volumes within the NW than the SW. In addition, the fact that no significant change was observed in the SW before and after installation supports the conclusion that storm runoff events remained relatively consistent over the course of the 8-year study.

Forty-four storm events were plotted and evaluated for changes in suspended sediment concentrations before and after installation of the AGSS. There was a noticeable decrease in the event suspended sediment concentrations in the NW after the installation of the AGSS (figure 7). Further statistical analysis of the NW also shows a significant average decrease $(p=0.02)$ from $971.61 \mathrm{mg} \mathrm{L}^{-1}$ before installation to $262.86 \mathrm{mg} \mathrm{L}^{-1}$ after (table 2). Evaluation of the SW revealed no significant $(p=0.43)$ differences in event mean suspended sediment concentrations before and after AGSS installation, with values of 310.57 and $360.57 \mathrm{mg} \mathrm{L}^{-1}$, respectively (table 2). These results support the claim that the AGSS is effective in reducing the concentrations of suspended sediments in runoff that is reaching nearby surface waters.

These aforementioned results are further strengthened by previous research conducted on the trapping efficiencies of sedimentation basins. Edwards et al. (1999) concluded sedimentation basins to be $87 \%$ to $97 \%$ efficient in removing the suspended sediments of agricultural runoff from a 2-year, 24-hour design storm. A more recent study by Fiener et al. (2005) evaluated the trapping efficiency of small detention ponds with similar design specifications as the AGSS in agricultural systems. These small ponds reportedly were able to trap between $54 \%$ and $85 \%$ of the incoming suspended sediment.

Between basin comparisons of the NW and SW also shows a significant change before and after the installation of the AGSS. Average suspended sediment concentrations per event are significantly different $(<0.002)$ between the NW and SW before installation (table 2). However, the mean event concentrations of the NW and SW after the AGSS was installed were $262 \mathrm{mg} \mathrm{L}^{-1}$ and $360 \mathrm{mg}$ $\mathrm{L}^{-1}$, respectively. Considering that the NW is the basin being used for agricultural practices, these results show that the installation of an AGSS can reduce suspended sediment concentrations in runoff to levels less than those seen in the nonagricultural basin (SW).

Particle Size Analysis. Particle size distributions from samples taken from within the AGSS were similar and suggest sediment deposition. The greatest proportion of clay and silt sized particles, as well as the smallest proportion of sand sized particles, were found within the surface sample of each soil core $(0$ to $9 \mathrm{~cm}$ [0 to $3.54 \mathrm{in}])$ taken within the AGSS (table 1). None of the surface samples contained particles greater than $400 \mu \mathrm{m}$; however, almost all subsurface samples contained some proportion of the larger sand sized particles, 


\section{Figure 6}

Total runoff minus baseflow $\left(\mathrm{L} \mathrm{ha}^{-1}\right.$ event $\left.^{-1}\right)$ and precipitation $(\mathrm{mm})$ for each of the 68 sampled events from 2001 to 2008 at both north watershed (NW) and south watershed (SW) sites. Differences in runoff (north - south) is also presented in the bottom plot.

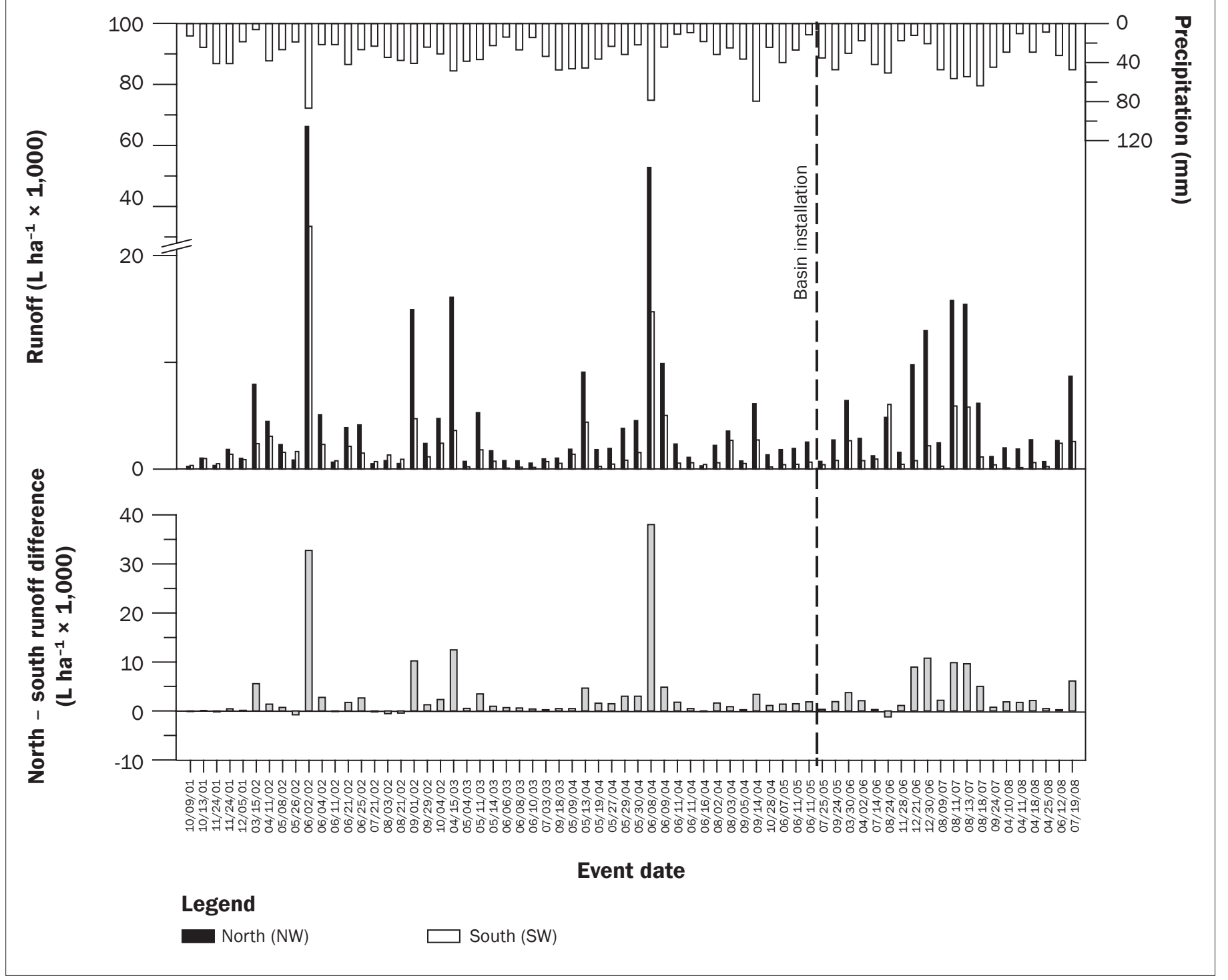

ranging between 400 and $1000 \mu \mathrm{m}$ (figure 8). This suggests that the surface samples were not representative of the native soil but were rather the result of the settling and removal of the runoff transported clay and silt from the ridge top and valley lying above the AGSS. This also suggests that the larger sand sized particles are being removed from storm runoff before reaching the AGSS.

Evaluation of surface soil samples taken from within the AGSS as well as the ridge top and valley lying above the AGSS revealed differences in the proportion of sand, silt, and clay at each location (figure 9). Use of the Wilcox test indicated that the amount of sand was significantly $(p<0.001)$ less in the AGSS (12\%) than in the valley (29\%) and the amount of clay was significantly $(\mathrm{p}<0.001)$ greater in the AGSS (37\%) than the valley (29\%) (table 3). The Wilcox test also indicated significantly $(p$-value $<0.05)$ greater amounts of sand and clay, as well as significantly less amounts of silt, in the AGSS in comparison to the ridge (table 3$)$. The average percentages of sand, silt, and clay in samples taken from the AGSS were $12 \%, 51 \%$, and $37 \%$, respectively (table 3). Samples taken from the ridge had average values of $5 \%$ for sand, $62 \%$ for silt, and $32 \%$ for clay (table 3 ).

The overall comparison of all samples taken outside the AGSS to those taken inside indicates that clay was the only statistically significant ( $p$ $<0.001$ ) different texture (table 3). This was likely due to the overlapping data values col- lected from outside and within the AGSS in regards to sand and silt (figure 10). The average amount of clay is greater in the AGSS (37\%) than outside the AGSS (30\%) (table 3).

The AGSS was designed with the intention of slowing down and retaining surface runoff that originated from the flat top ridges and steep side slopes. The retained runoff water is then allowed to infiltrate and recharge groundwater. As a result of this infiltration, any sediment formally suspended in the runoff would be retained within the AGSS as long as the volume of water does not exceed the principle spillway. In this case, the trapping of suspended sediment would still occur; however, some material would be lost due to an insufficient retention time 


\section{Figure 7}

Total runoff suspended sediment minus baseflow suspended sediment $\left(\mathrm{mg} \mathrm{L}^{-1} \mathrm{event}^{-1}\right)$ and precipitation (mm) for each of the 44 sampled events from 2001 to 2008 at both north (NW) and south (SW) watersheds. Difference in suspended sediment (north - south) is also presented.

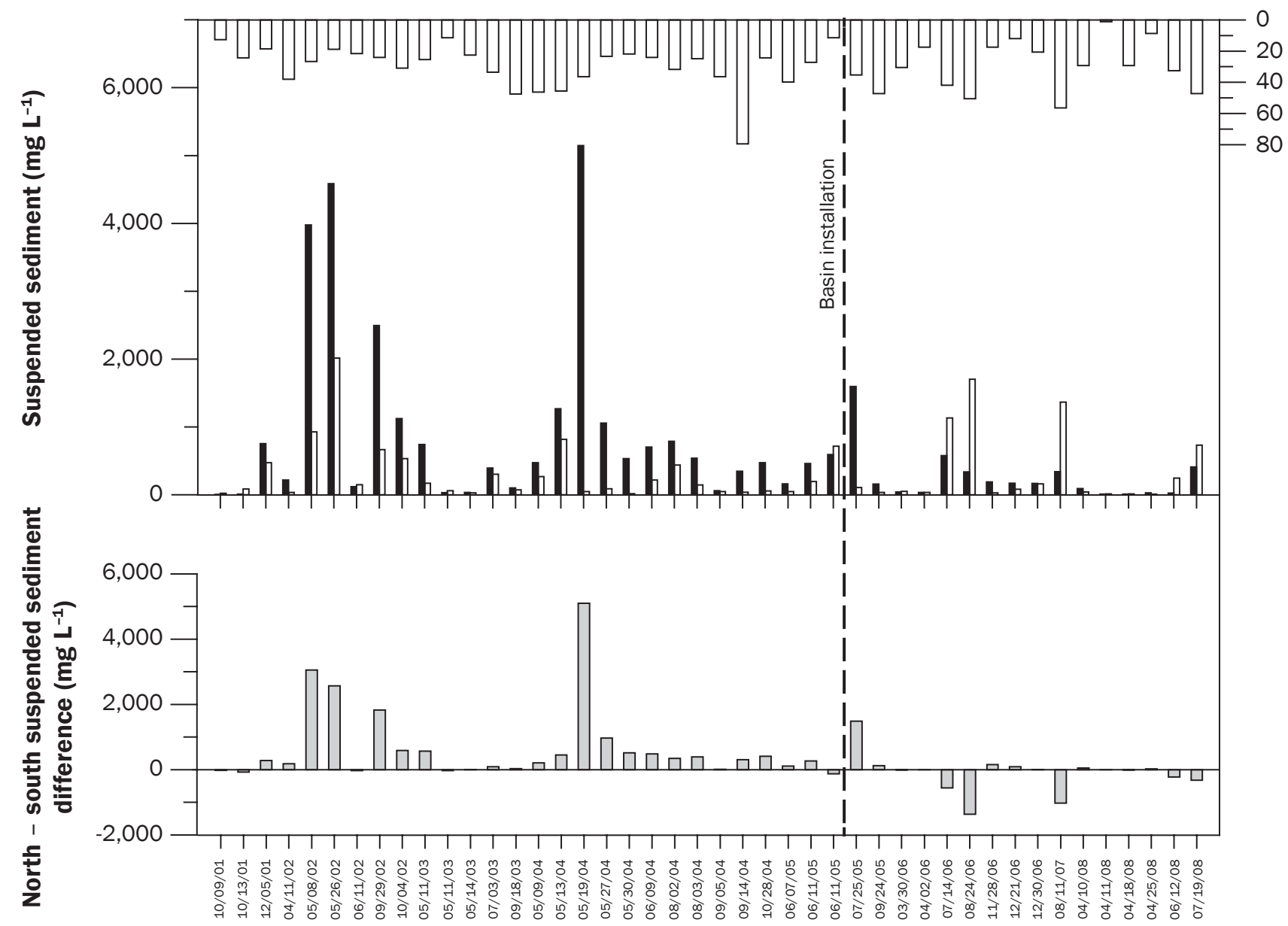

Event date

\section{Legend \\ North (NW)}

South (SW)

allowing complete sedimentation. Given that the surface subsample of cores taken from the AGSS contained the greatest proportion of clay-sized material, compared to samples outside the basin, it can be concluded that the AGSS was successful in trapping sediments.

\section{Summary and Conclusion}

The installation of AGSS in agricultural watersheds has the potential to improve surface water quality of nearby streams by reducing suspended sediment concentrations. The use of linear mixed model statistics to evaluate changes in precipitation, runoff, and suspended sediment concentrations proved efficient for these two paired watersheds. No significant changes were evident in the average event precipitation received by both the NW $(p=0.50)$ and SW ( $p=$ 0.34 ) basins, ruling out the possibility for changes in runoff and suspended sediment concentrations being correlated with varying precipitation. The AGSS proved to be successful in reducing the concentration of suspended sediments received by surface waters during storm runoff events in the NW $(p=0.02)$. In addition, implementation of the AGSS resulted in no significant change in the amount of storm runoff received by the surface waters of the NW $(p=0.15)$.

The PSA of soil samples taken within the impoundment of an AGSS, compared to those taken outside the AGSS, have significantly greater clay content $(p<0.001)$.
In addition, significantly greater clay content was observed in soil samples taken within the AGSS in comparison to those taken in the valley and ridge, with $p$-values less than 0.001 and 0.049 , respectively. Clay is often easily transported in runoff because of its small mass to volume ratio. In addition, their affinity to bind nutrients makes clays highly problematic in the eutrophication of surface waters. Evaluation of the eight individual soil cores taken behind the AGSS embankment revealed that the surface soil layer contained the greatest proportion of clay sized material in comparison to underlying subsoil samples. This affirms the hypothesis that the AGSS was successful in removing and trapping suspended sediments (clay). 


\section{Figure 8}

Particle size analysis of three soil samples taken from soil core N1. Corresponding textural classes are also identified based on the following particle size ranges: clay, $<2 \mu \mathrm{m}$; silt, 2 to 50 $\mu \mathrm{m}$; and sand, 50 to $2,000 \mu \mathrm{m}$.

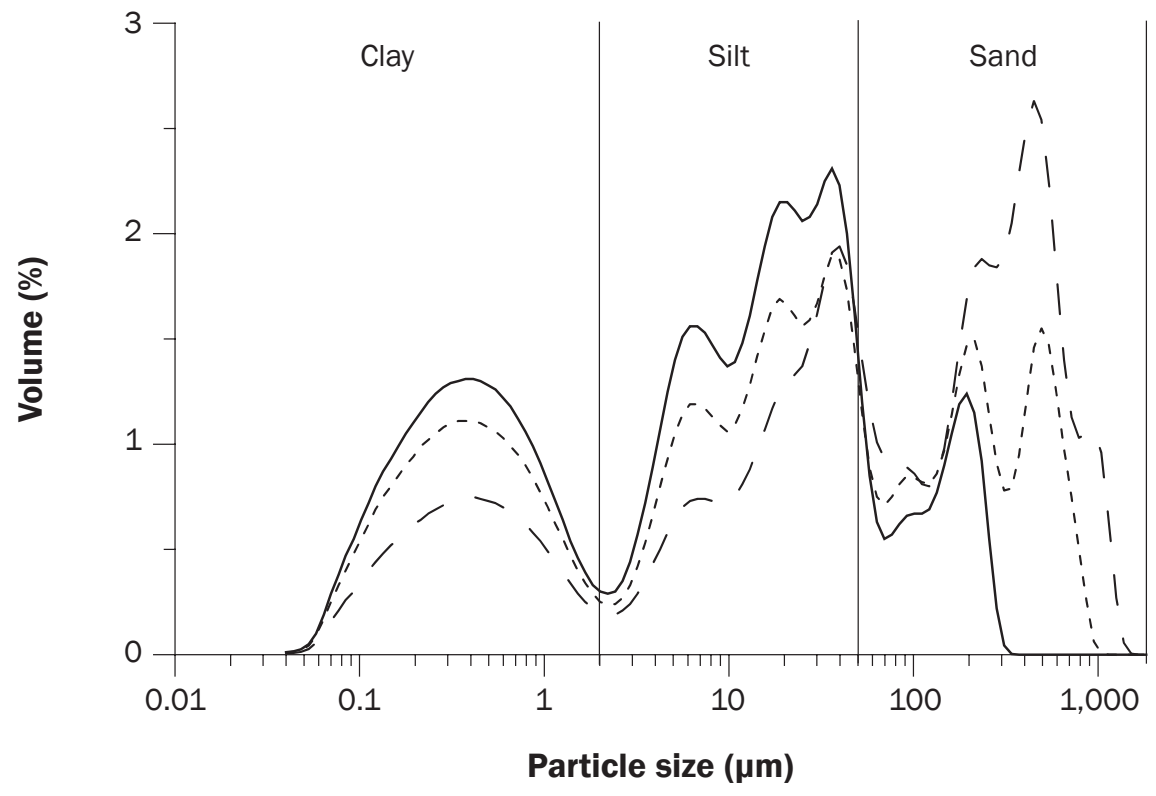

Legend

Subsample depth

- 0 to $2.5 \mathrm{~cm}$

- - - 2.5 to $5 \mathrm{~cm}$

- $\quad-25$ to $27.5 \mathrm{~cm}$

\section{Figure 9}

Box plots of the various soil textures (sand, silt, and clay) for surface soil samples taken within the at-grade stabilization structure (AGSS) and adjacent valley and ridge. The number of samples taken at each location are as follows: valley $=6$, ridge $=3$, and AGSS $=8$.

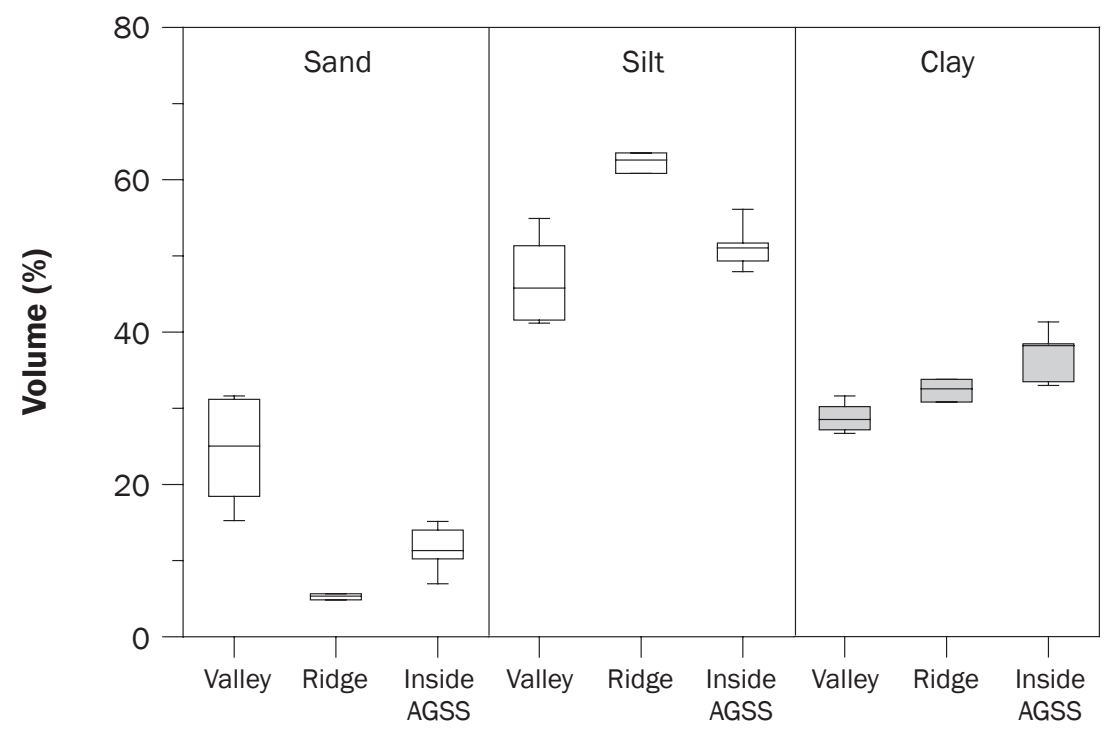

\section{Acknowledgements}

Partial funding for this study was provided by the University of Wisconsin Extension-Discovery Farms Program, the Wisconsin Department of Natural Resources, and the US Geological Survey. Funding was also provided by HATCH (NC-1178). Thanks to Joe Bragger and family for their cooperation in conducting this research. Thanks also to the US Geological Survey-Wisconsin Water Science Center for their help in installing and maintaining equipment as well as collecting data.

\section{Disclaimer}

Any use of trade, product, or firm names is for descriptive purposes only and does not imply endorsement by University of Wisconsin-Madison or the US Government to the exclusion of others.

\section{References}

American Public Health Association, American Water Works Association, Water Environment Federation. 1998. Standard methods for the examination of water and wastewater, 20th ed.Washington DC:American Public Health Association.

Arriaga, FJ., B. Lowery, and M.M. Mays. 2006. A fast method for determining soil particle size distribution using a laser instrument. Soil Science 171:663-673.

Barrett, M.E. 2008. Comparison of BMP performance using the international BMP database. Journal of Irrigation and Drainage Engineering 134(5):556-561.

Clayton, L., and J.W. Attig. 1990. Geology of Sauk County, Wisconsin. Wisconsin Geological and Natural History Survey Information Circular 67. Madison, WI:Wisconsin Geological and Natural History Survey.

Corsi, S.R., D.J. Owens, and R.T. Bannermen. 1997. Unitarea loads of suspended sediment, suspended solids, and total phosphorus from small watersheds in Wisconsin. US Geological Survey. Fact Sheet FS-195-97. Reston, VA: US Geological Survey.

Czapar, G.F., J.M. Laflen, G.F. McIsaac, and D.P. McKenna. 2005. Effects of erosion control practices on nutrient loss. In Final Report: Gulf Hypoxia and Local Water Quality Concerns Workshop, Ames, Iowa, September 26-28, 2005, 117-127. Ames, IA: Upper Mississippi River Sub-basin Hypoxia Nutrient Committee.

Edwards, C.L., R.D. Shannon, and A. Jarrett. 1999. Sedimentation basin retention efficiencies for sediment, nitrogen, and phosphorus from simulated agricultural runoff. Transactions of the American Society of Agricultural Engineers 42(2):403-409.

Fiener, P., K. Auerswald, and S. Weigand. 2005. Managing erosion and water quality in agricultural watersheds by small detention ponds. Agriculture Ecosystems and Environment 110:132-142.

Frolking, T.A., M.L. Jackson, and J.C. Knox. 1983. Origin of red clay over dolomite in the loess-covered Wisconsin driftless uplands. Soil Science Society of America Journal 47:817-820.

Gebert, W.A., and W. Krug. 1996. Streamflow trends in Wisconsin's driftless area. Water Resources Bulletin 32(4):733-744. 
Table 3

Average percentage sand, silt, and clay for surface soil samples collected on the ridge, valley, and within the at-grade stabilization structure (AGSS). Averages are on a percentage volume basis. Statistics are also presented to determine significant differences in means between valley vs. AGSS and ridge vs. AGSS.

\begin{tabular}{|c|c|c|c|}
\hline & $\begin{array}{l}\text { Sand } \\
\text { (\%) }\end{array}$ & $\begin{array}{l}\text { Silt } \\
(\%)\end{array}$ & $\begin{array}{l}\text { Clay } \\
\text { (\%) }\end{array}$ \\
\hline \multicolumn{4}{|l|}{ Valley vs. AGSS } \\
\hline Valley average & 29 & 47 & 29 \\
\hline AGSS average & 12 & 51 & 37 \\
\hline \multicolumn{4}{|l|}{ Statistics † } \\
\hline Wilcox test & $<0.001 *$ & 0.142 & $<0.001 *$ \\
\hline \multicolumn{4}{|l|}{ Ridge vs. AGSS } \\
\hline Ridge average & 5 & 62 & 32 \\
\hline AGSS average & 12 & 51 & 37 \\
\hline \multicolumn{4}{|l|}{ Statistics } \\
\hline Wilcox test & $0.012^{*}$ & $0.012 *$ & $0.049 *$ \\
\hline \multicolumn{4}{|c|}{ Inside vs. Outside } \\
\hline Outside average & 18 & 52 & 30 \\
\hline Inside average & 12 & 51 & 37 \\
\hline \multicolumn{4}{|l|}{ Statistics } \\
\hline Wilcox test & 0.277 & 1.000 & $<0.001 *$ \\
\hline
\end{tabular}

* Significant at $p<0.05$.

$\dagger$ Wilcox test is a nonparametric test to determine a significant change in means with nonnormally distributed data.

‡ Outside includes samples from both the ridge and valley. Inside includes samples from the AGSS.

\section{Figure 10}

Box plots of the various soil textures (sand, silt, and clay) for surface soil samples taken outside and inside of the at-grade stabilization structure (AGSS). The number of samples taken at each location are as follows: outside $\mathrm{AGSS}=9$ and inside $\mathrm{AGSS}=8$.

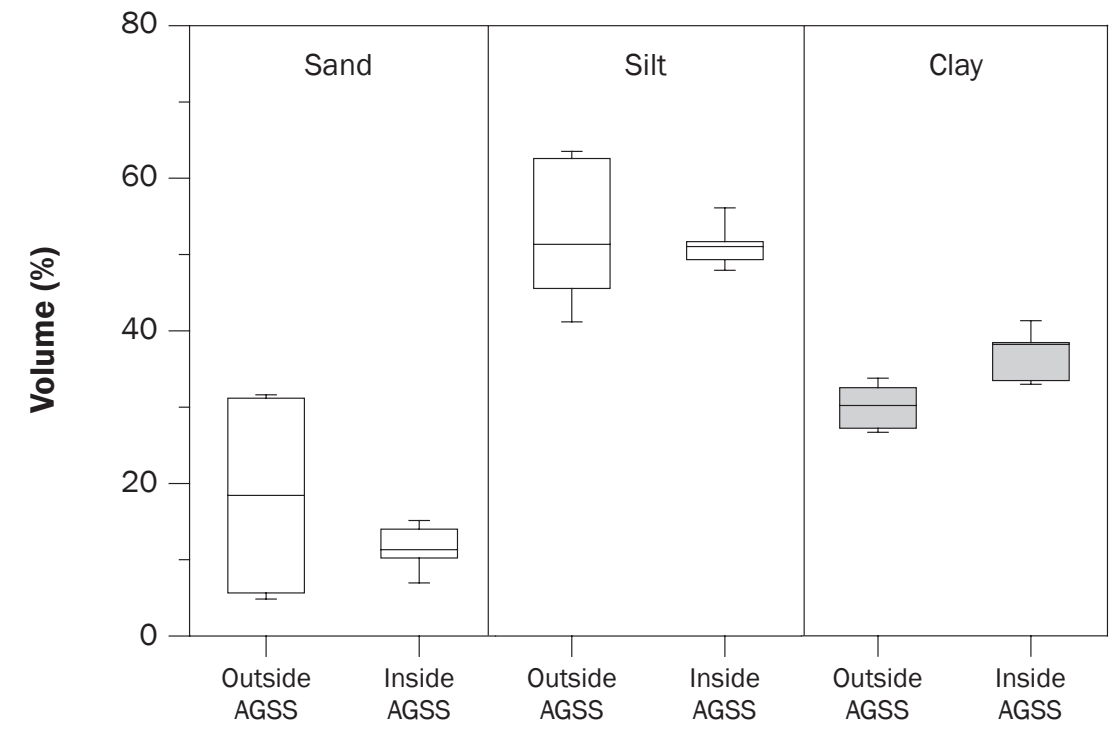

Gebert, W.A., M.J. Radloff, E.J. Considine, and J.L. Kennedy. 2007. Use of streamflow data to estimate base-flow/ ground-water recharge for Wisconsin. Journal of American Water Resources Association 43(1):220-236.

Helms, D.J., G.A. Pavelis, S. Argabright, R.G. Cronshey, and R.H. Sinclair. 1996. National soil conservation policies: A historical case study of the driftless area. Agricultural History 70(2):377-394.

Juckem, P.F, R.J. Hunt, M.P. Anderson, and D.M. Robertson. 2008. Effects of climate and land management change on streamflow in the driftless area of Wisconsin. Journal of Hydrology 355:123-130.

Krug, W. 1996. Simulation of temporal changes in rainfall runoff characteristics, Coon Creek Basin, Wisconsin. Water Resources Bulletin 4:745-752.

Lowery, B., J. Swan, T. Schumacher, and A. Jones. 1995. Physical properties of selected soils by erosion class. Journal of Soil and Water Conservation 50(3):306-311.

Mann, H.B., and D.R. Whitney. 1947. On a test of whether one or two random variables is stochastically larger than the other. Annals of Mathematical Statistics 18(1):50-60.

Potter, K. 1991. Hydrological impacts of changing land management practices in a moderate-sized agricultural catchment. Water Resources Research 27(5):845-855.

Pruski F.F, and M.A. Nearing. 2002. Runoff and soil-loss responses to changes in precipitation: A computer simulation study. Journal of Soil and Water Conservation 57(1):7-16.

Stuntebeck,T.D., M.J. Komiskey, D.W. Owens, and D.W. Hall. 2008. Methods of data collection, sample processing, and data analysis for edge-of-field, stream gaging, subsurfacetile, and meteorological stations at Discovery Farms and Pioneer Farm in Wisconsin, 2001-7. Reston, VA: US Geological Survey.

USDA NRCS (USDA Natural Resources Conservation Service). 2005. Construction plan for BMP\# 830 grade stabilization structure (410) - Wisconsin Standard Drawing no. WI-001. Washington, DC: USDA Natural Resources Conservation Service.

USDA NRCS. 2009a. Official soil series descriptions (OSD). Washington, DC: USDA Natural Resources Conservation Service. http://soils.usda.gov/technical/ classification/osd/index.html.

USDA NRCS. 2009b. Soil data explorer. Washington, DC: USDA Natural Resources Conservation Service. http:// websoilsurvey.nrcs.usda.gov/app/HomePage.htm.

USEPA (United States Environmental Protection Agency). 1983. Methods for chemical analysis of water and wastes. EPA-600479020, Method 160.4. Washington, DC: Environmental Protection Agency.

Wilcoxon, F. 1945. Individual comparisons by ranking methods. Biometrics Bulletin 1(6):80-83

Wisconsin State Climatology Office. 2007. Divisional climate data: West Central Wisconsin. Madison, WI: University of Wisconsin-Madison, Wisconsin State Climatology Office. http://www.aos.wisc.edu/ sco/clim-history/ division/4704-climo.html. 